\title{
Chemistry of polyhalogenated nitrobutadienes, 10 : Synthesis of highly functionalized heterocycles with a rigid 6-amino-3-azabicyclo[3.1.0]hexane moiety
}

\author{
Viktor A. Zapol'skii ${ }^{1}$, Jan C. Namyslo ${ }^{1}$, Armin de Meijere ${ }^{2}$ \\ and Dieter E. Kaufmann*1
}

\section{Full Research Paper}

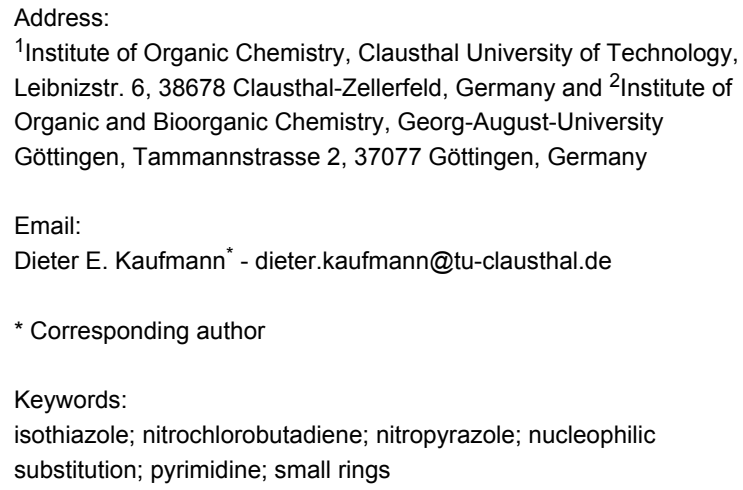

${ }^{1}$ Institute of Organic Chemistry, Clausthal University of Technology, Leibnizstr. 6, 38678 Clausthal-Zellerfeld, Germany and ${ }^{2}$ Institute of Organic and Bioorganic Chemistry, Georg-August-University Göttingen, Tammannstrasse 2, 37077 Göttingen, Germany

\begin{abstract} and 28 proved to be only partially feasible.

\section{Introduction}

Nitropolychlorobutadienes are potent precursors for a variety of highly functionalized acyclic and (hetero)cyclic compounds. The readily accessible 2-nitroperchloro-1,3-butadiene (3) [1] is one of the most prominent members of this rather new class of dienes. During the past nine years we have published the syntheses of a wide range of diverse substance classes, applying this useful starting material [2-7].
\end{abstract}

The nitropolychlorobutadienes $\mathbf{3}, \mathbf{4}$ are valuable building blocks for various amination and successive heterocyclization products. Nucleophilic substitution reactions of the partially protected, bioactive amines $\mathbf{1}, \mathbf{2}$ with either vinyl, imidoyl or carbonyl chlorides result in the formation of the enamines $\mathbf{1 1}, \mathbf{1 2}, \mathbf{1 3}, \mathbf{1 6}, \mathbf{2 5}$, the amidine $\mathbf{6}$, and the amides $\mathbf{2 0}, \mathbf{2 1}$, respectively. In the following, cyclization to the highly functionalized pyrazoles $\mathbf{2 7}, \mathbf{2 8}$, pyrimidine $\mathbf{2 6}$ and pyridopyrimidine $\mathbf{2 4}$ succeeded. Deprotection of $\mathbf{2 1}, \mathbf{1 2}$

The present work focuses on pharmacologically promising derivatives of the protected 6-amino-3-azabicyclo[3.1.0]- hexanes 1 and 2, which are obtained upon reaction with polychloronitrobutadienes 3 and $\mathbf{4}$ (Figure 1).

The rigid bisamine 6-amino-3-azabicyclo[3.1.0]hexane is an essential building block of several pharmaceuticals, such as the potent gyrase inhibitor Trovafloxacin (Figure 2) [8,9]. As a $4^{\text {th }}$ generation topoisomerase inhibitor, this fluoroquinolone anticipates replication of the bacterial DNA [10]. Other azabicyclo[3.1.0] hexane derivatives, for example with oxo-, oxazolidino-, quinolino-, oxobenzothiazolo[3,2-a]quinolino, or 


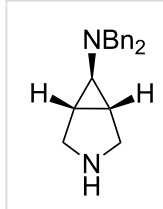

1

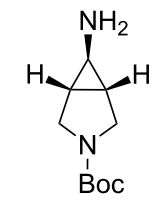

2<smiles>O=[N+]([O-])C(=C(Cl)Cl)C(Cl)Cl</smiles>

3<smiles>O=[N+]([O-])/C=C(/Cl)C(Cl)Cl</smiles>

4
Figure 1: Promising starting materials for biologically active compounds.

pyrrolidino substituents, exhibit remarkable antibacterial as well as antiprotozoal activity [11-15]. Furthermore, the 2-azabicyclo[3.1.0]hexane derivative of 3-hydroxyadamantylglycine, named Saxagliptin, is a pharmaceutical of the dipeptidyl peptidase IV (DPP-4) inhibitor class against type 2 diabetes mellitus and entered the market in 2009 (Figure 2) [16].

\section{Results and Discussion}

Driven by the promising stepwise reactivity of the highly substituted butadienes 3, 4 and with the above mentioned hints to biological activities in mind, we set out to develop structural conjunctions of the nitropolychlorobutadienes $\mathbf{3}$ and $\mathbf{4}$ with the 3-azabicyclo[3.1.0]hexane building blocks $\mathbf{1}$ and 2. Upon treatment with $N, N$-dibenzyl-3-azabicyclo[3.1.0]hexan-6-amine (1) in methanol the (tetrachloroallylidene)hydrazine $5[4,7]$ derived from 3 reacted in a formal nucleophilic substitution at the imidoyl chloride unit to give the derivative 6 in $80 \%$ isolated<smiles>NC1[C@H]2CN(c3nc4c(cc3F)c(=O)c(C(=O)O)cn4-c3ccc(F)cc3F)C[C@H]12</smiles>

Trovafloxacin

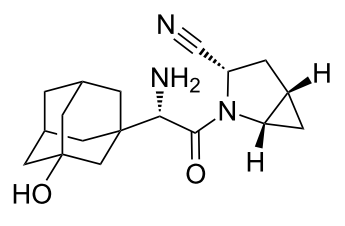

Saxagliptin
Figure 2: Pharmaceuticals bearing an azabicyclo[3.1.0]hexane unit.

yield (Scheme 1). The interest in such compounds derives from the fact that a number of similar hydrazones, e.g., phenyl(phenylchloromethylidene)hydrazine, exhibit fungicidal, antibacterial, and fungistatic activity $[17,18]$.

In view of the insecticidal properties of some recently published [19] analogues of imidacloprid ( $N$-[1-[(6-chloro-3pyridyl)methyl]-4,5-dihydroimidazol-2-yl]nitramide), the substitutions of the imidazolidines $\mathbf{9}$ and $\mathbf{1 0}$ with $\mathbf{1}$ were also tested. Compounds $\mathbf{9}$ and $\mathbf{1 0}$ were prepared from the nitrodiene $\mathbf{3}$ and the ethylenediamines $\mathbf{7}$ and $\mathbf{8}$. The formal nucleophilic substitution of the $\alpha$-chloro substituent within the trichlorovinyl group of $\mathbf{9}$ and $\mathbf{1 0}$ by the amine $\mathbf{1}$ proceeded smoothly to give both of the novel imidacloprid analogues $\mathbf{1 1}$ and 12, each in $90 \%$ yield (Scheme 2 ).<smiles>CC(=O)OCC(=O)O[Na]</smiles>

5

$(80 \%)$<smiles>NC1[C@@H]2CN(/C(=N\Nc3ccc([N+](=O)[O-])cc3)C(Cl)=C(Cl)Cl)C[C@H]1[C@H]2Cc1ccccc1</smiles>

6

Scheme 1: Synthesis of the azabicyclic hydrazone 6.

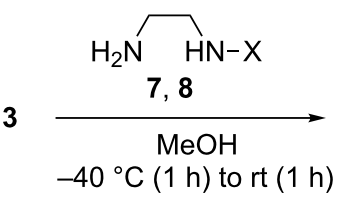<smiles>[X]N1CCN/C1=C(/C(Cl)=C(Cl)Cl)[N+](=O)[O-]</smiles><smiles>C[As](=O)(O)c1ccccc1</smiles>

9, $47 \%$

$10,68 \%$<smiles>O=[N+]([O-])C1=C2NCCN2[Y](Cl)C(N2CC[C@H](NCc3ccccc3)C2)=C1Cl</smiles>

$12,90 \%$

7, 9, $11 \quad \mathrm{X}=$ 2-chloropyrid-5-ylmethyl

8, 10,12 $X=2$-chlorothiazol-5-ylmethyl 
It is worth noting that all these nitroenamines 9-12 are formed as $E$-isomers, which are stabilized by an intramolecular hydrogen bridge bond in a six-membered pseudocycle (Figure 3).

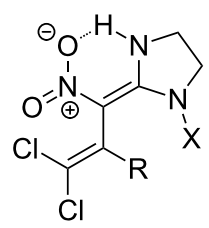

Figure 3: Stabilizing hydrogen bond in nitrobutadiene-derived imidacloprid analogues 9-12.

Upon treatment of 1,3-dinitro-1,4,4-trichlorobutadiene (4), which was obtained in a four-step sequence from 1,2dichloroethylene (mixture of diastereomers) [20,21], with a fourfold excess of the azabicyclo[3.1.0]hexane $\mathbf{1}$ in methanol at $-40{ }^{\circ} \mathrm{C}$, a twofold vinylic substitution led to the 4,4 bis(aminoazabicyclo[3.1.0]hexyl)-1-chloro-1,3-dinitrobutadiene $\mathbf{1 3}$ in $80 \%$ yield (Scheme 3 ).

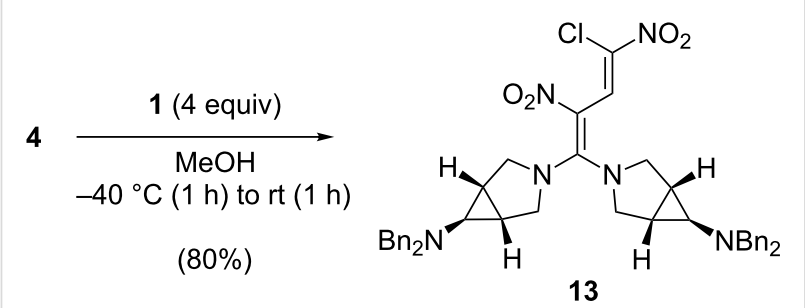

Scheme 3: Synthesis of the 4,4-bis(aminoazabicyclo[3.1.0]hexyl)-1chloro-1,3-dinitrobutadiene 13.

In an analogous treatment of the pentachloronitrobutadiene $\mathbf{3}$ with a fourfold excess of 1,2,4-triazole in diethyl ether the 4,4bistriazolyltrichloronitrobutadiene 14 ( $92 \%$ yield) was obtained [22] and turned out to be an appropriate substrate for a transamination, as the triazole is an excellent leaving group. Thus, by treatment of 14 with $p$-phenetidine the 4-triazolyl-4-(4ethoxyphenylamino)butadiene $\mathbf{1 5}$ was obtained in $83 \%$ yield. Subsequent reaction of $\mathbf{1 5}$ with tert-butyl 6-amino-3-azabicyclo[3.1.0]hexane-3-carboxylate (2) provided the tris(amino)butadiene $\mathbf{1 6}$ in $70 \%$ yield (Scheme 4).

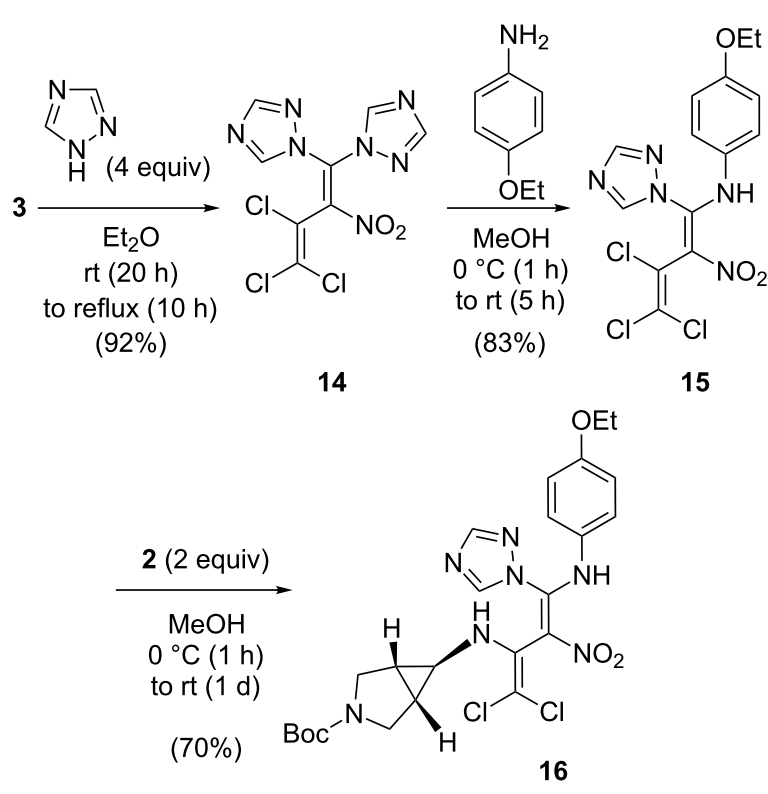

Scheme 4: Synthesis of the highly substituted trisaminodichloronitrobutadiene 16.

It is noteworthy that the diaminonitrovinyl moiety in compound 15 remains unaffected in the last substitution step. Apparently, the 2-nitroenamine substructure in $\mathbf{1 5}$ is less electrophilic at C-3 than its conceivable tautomeric structure 16A would suggest. After the third formal nucleophilic substitution at $\mathrm{C}-2$, the resulting product $\mathbf{1 6}$ has a second enamine substructure as in 16A, rather than a dichloromethylimine subunit as in 16B. This is obvious from the ${ }^{1} \mathrm{H}$ NMR spectrum of $\mathbf{1 6}$, which does not show a signal corresponding to a dichloromethyl proton, and in addition the ${ }^{13} \mathrm{C}$ NMR spectrum shows four signals associated with olefinic carbon atoms (Figure 4).<smiles>[R]NC(=C(Cl)Cl)C(C(=[N+])n1cncn1)=[N+]([O-])O</smiles>

iminonitronate 16A<smiles>[R]NC(=C(Cl)Cl)C(N[AlH2])=C(N[GaH])n1cncn1</smiles>

16

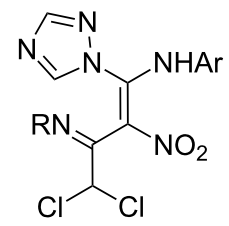

dichloromethylimine

Figure 4: Conceivable tautomeric structures of $\mathbf{1 6 .}$ 
In addition to the direct attachment of heteroatoms or even heterocycles to nitropolychlorobutadienes by formal vinylic nucleophilic substitution reactions as described above, it was of interest to incorporate a persubstituted diene unit as in $\mathbf{3}$ and $\mathbf{4}$ into a heterocycle. For example, the isothiazole 17 was obtained from the nitrodiene 3 upon treatment with elemental sulfur at $200{ }^{\circ} \mathrm{C}$ [23]. Subsequent reaction with fuming nitric acid provided the dichloroisothiazolocarboxylic acid 18 [24], which could be easily converted with thionyl chloride to the corresponding acid chloride 19 (93\% yield). The latter smoothly reacted with the azabicyclohexane derivatives $\mathbf{1}$ and $\mathbf{2}$ to provide the corresponding amides 20 and $\mathbf{2 1}$, respectively (Scheme 5). These amides $\mathbf{2 0}$ and $\mathbf{2 1}$ are hot candidates for biological testing, as some known amides of 4-chloroisothiazol-3carboxylic acid have been shown to exhibit high antibacterial activity [25-27].

The high number of heteroatoms in $\mathbf{2 0}$ and $\mathbf{2 1}$, accompanied by only a few hydrogen atoms, requires ${ }^{1} \mathrm{H} /{ }^{13} \mathrm{C}-2 \mathrm{D}$ as well as nitrogen NMR spectra for structural assignments. For example, aside from aromatic protons in $\mathbf{2 0}$, the methylene groups within the pyrrolidine ring each appear as a set of one single doublet (geminal coupling only) and a doublet of doublets (with additional coupling to the bridgehead proton due to an appropriate dihedral angle). Narrow shifts of the corresponding carbon atoms were assigned by means of an HSQC spectrum. The benzylic methylene protons give two slightly separated doublets (each with the expected ${ }^{2} J$ coupling of about $13 \mathrm{~Hz}$ ). Appearing at 3.59 and $3.54 \mathrm{ppm}$, respectively, they are attached to isochronous carbon atoms at $59.0 \mathrm{ppm}$. Furthermore, the proton of the $\mathrm{NCH}$ fragment $\left({ }^{13} \mathrm{C}\right.$ NMR: $\left.\delta=47.3 \mathrm{ppm}\right)$ of the cyclopropane ring appears as a triplet at $1.54 \mathrm{ppm}(J=2.3 \mathrm{~Hz})$. Interestingly, the chemical shift of both of the bridgehead protons is $1.35 \mathrm{ppm}$ (dd, $J=4.2,2.3 \mathrm{~Hz}$ ), whereas the corresponding carbon atoms have slightly different chemical shifts of 25.5 and $24.5 \mathrm{ppm}$, respectively. Most of the quarternary carbon shifts are unambiguous, whereas an HMBC spectrum was necessary for the assignment of two downfield signals: $160.5 \mathrm{ppm}(\mathrm{C}=\mathrm{O})$ and 160.4 ppm (SC). ${ }^{14} \mathrm{~N}$ NMR (one-dimensional, direct detection) and an inverse-detected ${ }^{1} \mathrm{H} /{ }^{15} \mathrm{~N}-\mathrm{HMBC}$ gave the nitrogen shifts (internal $\mathrm{MeNO}_{2}$ at $\left.0.0 \mathrm{ppm}\right)$ : $-65.8 \mathrm{ppm}(\mathrm{C}=\mathrm{N}),-244.2 \mathrm{ppm}$ (NCO), and $-319.5 \mathrm{ppm}(\mathrm{NBn})$.

In addition to the twofold triazole substitution, the nitrodiene $\mathbf{3}$ was treated with four equiv of benzotriazole in THF. Thus, the bisbenzotriazole derivative 22 was obtained in $76 \%$ yield [28]. Having the target of further compounds with insecticidal activities in mind, 22 was treated with 2-aminopyridine, but the simple substitution product, a benzotriazolyl-1-(pyrid-2ylamino)diene, which must have been formed initially, apparently must have tautomerized to a pyridin-2(1H)-imine derivative, which then underwent cyclization by a formal nucleophilic substitution leading to the $4 H$-pyrido[1,2- $a$ ]pyrimidine 23. The remaining benzotriazole group in $\mathbf{2 3}$, which is acti-

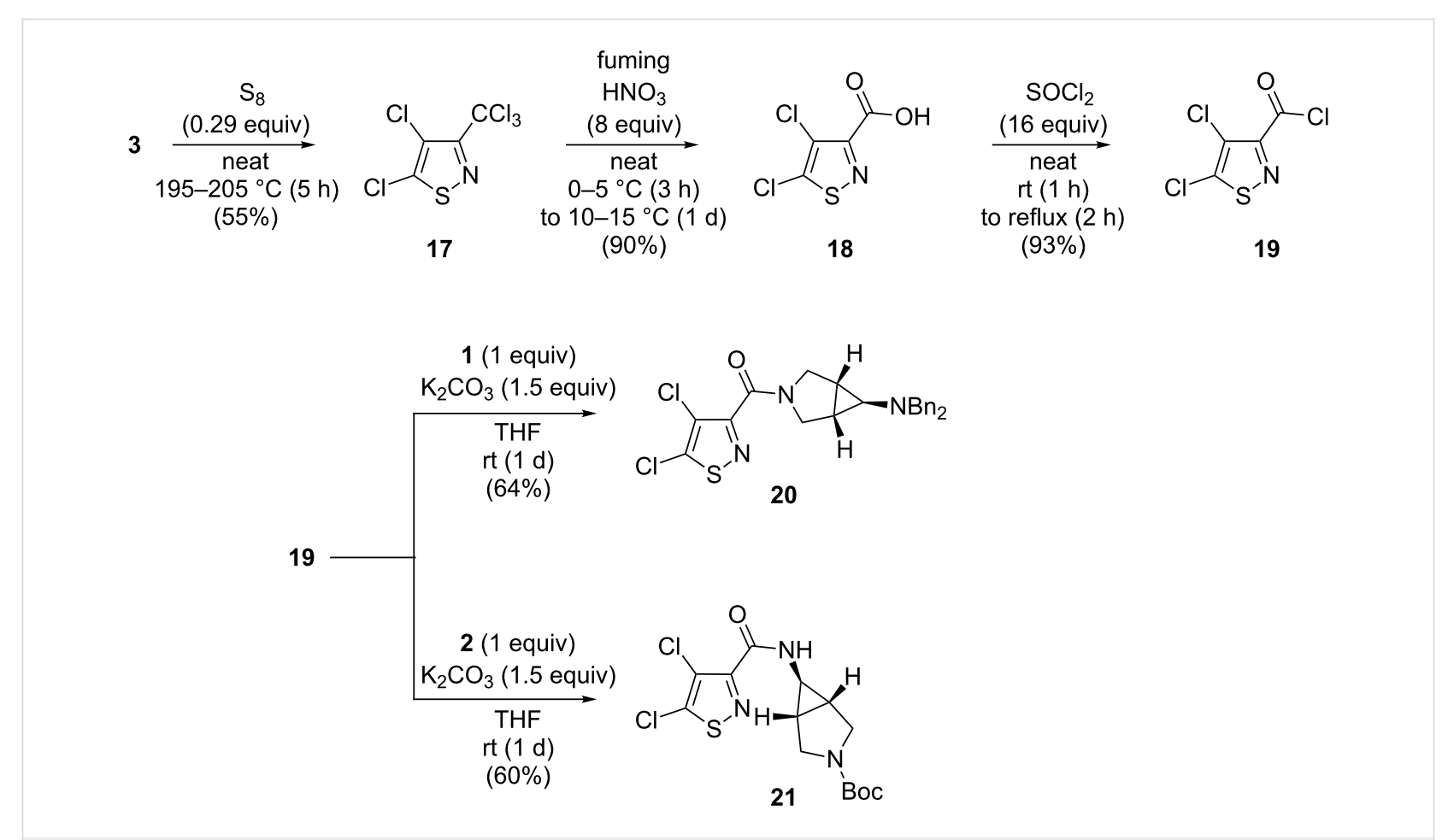


vated by the adjacent nitro substituent allows for a further nucleophilic substitution. Therefore, upon treatment with the azabicyclohexane 1 under mild conditions (methanol, rt) the enamine 24 was formed in $86 \%$ yield (Scheme 6). Similar pyrido[1,2-a]pyrimidines show antiviral [29], antithrombotic [30] and antibacterial [31-34] activities.

Alternatively, conversion of bis(benzotriazolyl)butadiene $\mathbf{2 2}$ with one equiv of amine 1 led to transamination at $\mathrm{C}-1$ of the butadiene to furnish the azabicyclohexyl-nitrobutadiene $\mathbf{2 5}$ in $95 \%$ yield. The latter, on one hand was converted by treatment with acetamidine hydrochloride in THF to the pyrimidine $\mathbf{2 6}$ (yield 58\%), which apparently proceeds by transamination and subsequent intramolecular $\mathrm{S}_{\mathrm{N}} \mathrm{Vin}$ reaction. The structure of an analogous derivative of this heterocycle was previously confirmed by X-ray crystallography [5]. On the other hand, nitrodiene $\mathbf{2 5}$ was treated with arylhydrazines to give the persubstituted aminonitropyrazoles $\mathbf{2 7 - 2 8}$ in $75-90 \%$ yield (Scheme 6).
A conceivable mechanism for the cascade reaction that leads to the pyrazoles $\mathbf{2 7}$ and $\mathbf{2 8}$ is presented in Scheme 7. Initially, the trichlorobutene $\mathbf{I}$ is formed upon addition of the arylhydrazine to the nitro-substituted butadiene 25. Subsequent elimination of benzotriazole results in the diaminobutadiene II, which tautomerizes to the stable amidine III. The pyrazoline IV is then formed by an intramolecular $\mathrm{S}_{\mathrm{N}} \mathrm{Vin}$ reaction. Finally, $\mathrm{HCl}$ elimination affords the pyrazoles $\mathbf{2 7}, \mathbf{2 8}$. The stimulus to investigate such compounds originated from the known pharmacological activities of 4-nitropyrazoles [35-42].

At the end of our synthetic work, three of the intricate 6-amino3-azabicyclo[3.1.0] hexane derivatives were subjected to common deprotection conditions on a micromole scale (Scheme 8). Interestingly, in the case of the removal of the $N$-Boc group from 21 by means of surplus trifluoroacetic acid under mild conditions, the corresponding free amine $\mathbf{2 9}$ was obtained in $83 \%$ yield, without any further optimization. However, accurately tailored conditions seemed to be neces-

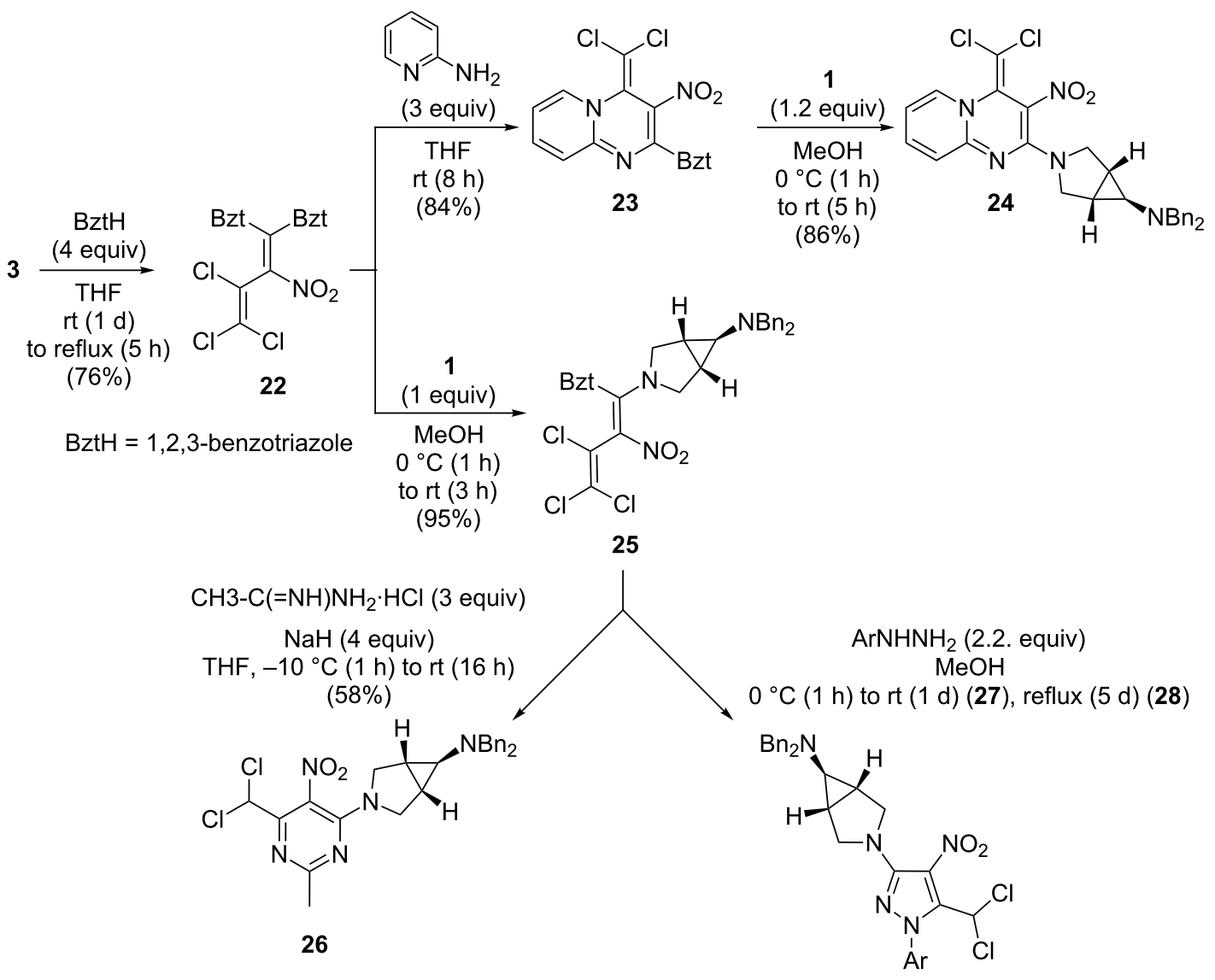

27, $\mathrm{Ar}=p$-chlorophenyl, $75 \%$

28, $\mathrm{Ar}=2,6$-dichloro-4-(trifluoromethyl)phenyl, 90\% 


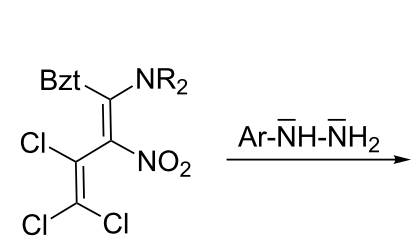

25

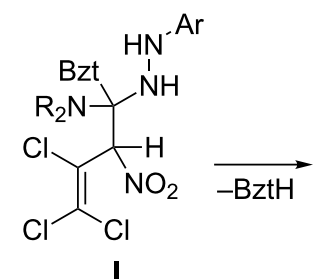<smiles>[R10]C(NN[Al])=C(C(Cl)=C(Cl)Cl)[N+](=O)[O-]</smiles><smiles>[R20]/C(=N/Br)C(C(Cl)=C(Cl)Cl)[N+](=O)[O-]</smiles>

III

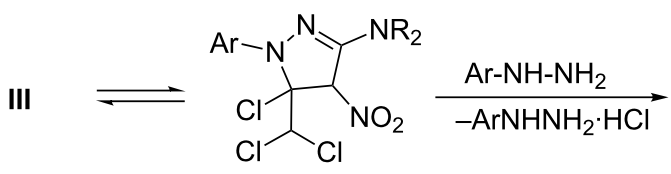

IV<smiles>[R20]c1nn([Al])c(C(Cl)Cl)c1[N+](=O)[O-]</smiles>

27,28

Scheme 7: Proposed reaction mechanism for the formation of 27, 28.

sary for the N-debenzylation of the protected amino compounds $\mathbf{1 2}$ and $\mathbf{2 8}$. The application of the usual reductive conditions (i.e., hydrogen under atmospheric pressure, palladium on charcoal suspended in, e.g., ethanol) to the protected amine $\mathbf{1 2}$ led to a multiple reaction involving the deprotection, a bisdechlorination and final hydrolysis of an intermediate imine. The resulting ketone 30 was isolated in $44 \%$ yield. On the other hand, the highly substituted dibenzylamino compound $\mathbf{2 8}$ showed another interesting reaction pathway: One of its benzyl groups was unmodified, even though the competing reduction of the dichloromethyl substituent took place to give the mono-
$\mathrm{N}$-benzylated rigid amine 31 in $45 \%$ yield. With $\mathrm{Pd} / \mathrm{C}$ at ambient hydrogen pressure and ethanol as a solvent, no reduction of the nitro group or the aromatic chlorine atoms in $\mathbf{1 2}$ and $\mathbf{2 8}$ was observed. To avoid the described side reactions, further experiments should comprise the optimization of the hydrogen volume and pressure as well as some fine tuning of the catalyst/ solvent system.

To the best of our knowledge, the transformation observed for compound 12, i.e., the reduction of a 1-amino-2,2-dichlorovinyl group to an acetyl substituent, is hitherto unprecedented.<smiles>[Z17]N1C[C@H]2[C@H](NC(=O)c3nsc(Cl)c3Cl)[C@H]2C1</smiles>

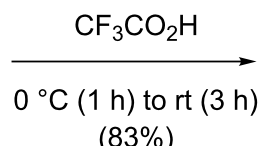

$(83 \%)$<smiles>O=[N+]([O-])/C(C(Cl)=C(Cl)Cl)=C1\NCCN1Cc1cnc(Cl)s1</smiles>

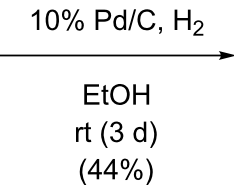

$(44 \%)$<smiles>O=C(c1ccccc1)[C@H]1[C@@H]2C[C@H]2CN1c1nn(-c2c(Cl)cc(C(F)(F)F)cc2Cl)c(C(Cl)Cl)c1[N+](=O)[O-]</smiles>

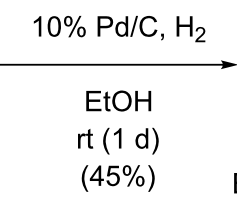<smiles>O=C1NC[C@]23CNC[C@@H]2[C@@H](N1)N3</smiles><smiles>CC(=O)/C(=C1/NCCN1Cc1cnc(Cl)s1)[N+](=O)[O-]</smiles>

30 
However, the individual parts of these multistep reactions, namely the conversion of the 1-amino-2,2-dichlorovinyl group to a dichloromethyl ketone and, in addition, the reductive bisdechlorination of a dichloromethyl group were recently published by our group [5,43].

\section{Conclusion}

Regioselective reactions of the nitrotrichlorobuta-1,3-dienes 3 and $\mathbf{4}$, some after initial transformations to other derivatives with exo-6- $N, N$-dibenzylamino-3-azabicyclo-[3.1.0]hexane (1) and exo-6-amino-3-(tert-butoxycarbonylaza)bicyclo[3.1.0]hexane (2), led to a series of potentially biologically active compounds, which are due to be tested in various assays.

\section{Supporting Information}

\section{Supporting Information File 1}

Experimental section.

[http://www.beilstein-journals.org/bjoc/content/

supplementary/1860-5397-8-69-S1.pdf]

\section{Acknowledgements}

This work was supported financially by Bayer AG (Leverkusen, Germany). The authors are grateful to Dr. C. Stratmann (Georg-August-Universität Göttingen, Germany) for samples of the bicyclic diamine derivatives $\mathbf{1}$ and $\mathbf{2}$ as well as to Dr. H. Frauendorf for HR-ESI MS. We thank Dr. G. Dräger (Leibniz-Universität Hannover, Germany) for ESI and EI highresolution mass spectra.

\section{References}

1. Potkin, V. I.; Zapol'skii, V. A.; Kaberdin, R. V. Izv. Akad. Nauk Bel., Ser. Khim. Nauk 1996, 40, 68-71.

2. Kaberdin, R. V.; Potkin, V. I.; Zapol'skii, V. A. Russ. Chem. Rev. 1997, 66, 827-842. doi:10.1070/RC1997v066n10ABEH000310

3. Zapol'skii, V. A.; Namyslo, J. C.; Adam, A. E. W.; Kaufmann, D. E. Heterocycles 2004, 63, 1281-1298. doi:10.3987/COM-04-10020

4. Zapol'skii, V. A.; Nutz, E.; Namyslo, J. C.; Adam, A. E. W.; Kaufmann, D. E. Synthesis 2006, 2927-2933. doi:10.1055/s-2006-950187

5. Zapol'skii, V. A.; Namyslo, J. C.; Altug, C.; Gjikaj, M.; Kaufmann, D. E. Synthesis 2008, 304-310. doi:10.1055/s-2007-990948

6. Zapol'skii, V. A.; Fischer, R.; Namyslo, J. C.; Kaufmann, D. E. Bioorg. Med. Chem. 2009, 17, 4206-4215. doi:10.1016/j.bmc.2009.01.001

7. Zapol'skii, V. A.; Namyslo, J. C.; Gjikaj, M.; Kaufmann, D. E. Z. Naturforsch., B 2010, 65b, 843-860.

8. Brighty, K. E. Azabicyclo Quinolone Carboxylic Acids. WO Patent 91/02526, March 7, 1991.

9. Fromtling, R. A.; Castañer, J. Drugs Future 1996, 21, 496-505.

10. Gootz, T. D.; Zaniewski, R.; Haskell, S.; Schmieder, B.; Tankovic, J.; Girard, D.; Courvalin, P.; Polzer, R. J. Antimicrob. Agents Chemother. 1996, 40, 2691-2697.
11. Komine, T.; Kojima, A.; Asahina, Y.; Saito, T.; Takano, H.; Shibue, T.; Fukuda, Y. J. Med. Chem. 2008, 51, 6558-6562. doi:10.1021/jm800800c

12. Sattigeri, J. A.; Andappan, M. M. S.; Kishore, K.; Thangathirupathy, S.; Sundaram, S.; Singh, S.; Sharma, S.; Davis, J. A.; Chugh, A.; Bansal, V. S. Bioorg. Med. Chem. Lett. 2008, 18, 4087-4091. doi:10.1016/j.bmcl.2008.05.101

13. Dinakaran, M.; Senthilkumar, P.; Yogeeswari, P.; China, A.; Nagaraja, V.; Sriram, D. Bioorg. Med. Chem. 2008, 16, 3408-3418. doi:10.1016/j.bmc.2007.11.016

14. Kumar, N.; Kaur, K.; Aeron, S.; Dharmarajan, S.; Silamkoti, A. D. V.; Mehta, A.; Gupta, S.; Chugh, A.; Gupta, J. B.; Salman, M.; Palle, V. P.; Cliffe, I. A. Bioorg. Med. Chem. Lett. 2007, 17, 5256-5260. doi:10.1016/j.bmcl.2007.06.081

15. Anquetin, G.; Greiner, J.; Mahmoudi, N.; Santillana-Hayat, M.; Gozalbes, R.; Farhati, K.; Derouin, F.; Aubry, A.; Cambau, E.; Vierling, P. Eur. J. Med. Chem. 2006, 41, 1478-1493. doi:10.1016/j.ejmech.2006.07.003

16. Savage, S. A.; Jones, G. S.; Kolotuchin, S.; Ramrattan, S. A.; Vu, T.; Waltermire, R. E. Org. Process Res. Dev. 2009, 13, 1169-1176. doi:10.1021/op900226j

17. Molodykh, Z. V.; Buzykin, B. I.; Kudrina, M. A.; Sysoeva, L. P.; Gazetdinova, N. G.; Neklesova, I. D.; Kitaev, Y. P. Pharm. Chem. J. 1980, 14, 162-169. doi:10.1007/BF00777380

18. Rector, D. L.; Folz, S. D.; Conklin, R. D.; Nowakowski, L. H.; Kaugars, G. J. Med. Chem. 1981, 24, 532-538. doi:10.1021/jm00137a011

19. Fischer, R.; Jeschke, P.; Erdelen, C.; Lösel, P.; Reckmann, U.; Kaufmann, D. E.; Zapol'skii, V. A. Halogenated Nitrobutadienes for Controlling Animal Pests. WO 03/040129 A1, May 15, 2003.

20. Zapol'skii, V. A.; Potkin, V. I.; Kaberdin, R. V. Vestsi Nats. Akad. Navuk Belarusi, Ser. Khim. Navuk 1993, 3, 76-80.

21. Zapol'skii, V. A.; Namyslo, J. C.; Blaschkowski, B.; Kaufmann, D. E. Synlett 2006, 3464-3468. doi:10.1055/s-2006-956490

22. Zapol'skii, V. A.; Potkin, V. I.; Nechai, N. I.; Kaberdin, R. V.; Pevzner, M. S. Russ. J. Org. Chem. 1997, 33, 1632-1637.

23. Kaberdin, R. V.; Potkin, V. I.; Ol'dekop, Y. A. Dokl. Chem. 1988, 300 , 173-175.

24. Kaberdin, R. V.; Potkin, V. I.; Ol'dekop, Y. A. Russ. J. Org. Chem. 1990, 26, 1347-1351.

25. Li, J.; Wakefield, B. D.; Ruble, J. C.; Stiff, C. M.; Romero, D. L.; Marotti, K. R.; Sweeney, M. T.; Zurenko, G. E.; Rohrer, D. C.; Thorarensen, A. Bioorg. Med. Chem. Lett. 2007, 17, 2347-2350. doi:10.1016/j.bmcl.2006.12.055

26. Kaizerman, J. A.; Gross, M. I.; Ge, Y.; White, S.; Hu, W.; Duan, J.-X.; Baird, E. E.; Johnson, K. W.; Tanaka, R. D.; Moser, H. E.; Bürli, R. W. J. Med. Chem. 2003, 46, 3914-3929. doi:10.1021/jm030097a

27. Bürli, R. W.; Ge, Y.; White, S.; Baird, E. E.; Touami, S. M.; Taylor, M.; Kaizerman, J. A.; Moser, H. E. Bioorg. Med. Chem. Lett. 2002, 12, 2591-2594. doi:10.1016/S0960-894X(02)00515-2

28. Zapol'skii, V. A.; Potkin, V. I.; Nechai, N. I.; Kaberdin, R. V. Russ. J. Org. Chem. 1993, 29, 731-734.

29. Ukrainets, I. V.; Bereznyakova, N. L.; Turaibei, I. A. Chem. Heterocycl. Comp. 2008, 44, 50-63. doi:10.1007/s10593-008-0012-x

30. Sturgeon, S. A.; Jones, C.; Angus, J. A.; Wright, C. E. Eur. J. Pharm. Sci. 2008, 587, 209-215. doi:10.1016/j.ejphar.2008.03.017 
31. Yoshida, K.-i.; Nakayama, K.; Ohtsuka, M.; Kuru, N.; Yokomizo, Y.; Sakamoto, A.; Takemura, M.; Hoshino, K.; Kanda, H.; Nitanai, H.; Namba, K.; Yoshida, K.; Inamura, Y.; Zhang, J. Z.; Lee, V. J.; Watkins, W. J. Bioorg. Med. Chem. 2007, 15, 7087-7097. doi:10.1016/j.bmc.2007.07.039

32. La Motta, C.; Sartini, S.; Mugnaini, L.; Simorini, F.; Taliani, S.; Salerno, S.; Marini, A. M.; Da Settimo, F.; Lavecchia, A.; Novellino, E.; Cantore, M.; Failli, P.; Ciuffi, M. J. Med. Chem. 2007, 50, 4917-4927. doi:10.1021/jm070398a

33. Barbeau, O. R.; Cano-Soumillac, C.; Griffin, R. J.; Hardcastle, I. R.; Smith, G. C. M.; Richardson, C.; Clegg, W.; Harrington, R. W.; Golding, B. T. Org. Biomol. Chem. 2007, 5, 2670-2677. doi:10.1039/b705095j

34. Yoshida, K.-i.; Nakayama, K.; Kuru, N.; Kobayashi, S.; Ohtsuka, M.; Takemura, M.; Hoshino, K.; Kanda, H.; Zhang, J. Z.; Lee, V. J.; Watkins, W. J. Bioorg. Med. Chem. 2006, 14, 1993-2004. doi:10.1016/j.bmc.2005.10.043

35. Aiello, E.; Aiello, S.; Mingoia, F.; Bacchi, A.; Pelizzi, G.; Musiu, C.; Setzu, M. G.; Pani, A.; La Colla, P.; Marongiu, M. E. Bioorg. Med. Chem. 2000, 8, 2719-2728. doi:10.1016/S0968-0896(00)00211-X

36. Luo, C.; Xie, P.; Marmorstein, R. J. Med. Chem. 2008, 51, 6121-6127. doi:10.1021/jm800539g

37. Firestine, S. M.; Wu, W.; Youn, H.; Davisson, V. J. Bioorg. Med. Chem. 2009, 17, 794-803. doi:10.1016/j.bmc.2008.11.057

38. Schepetkin, I. A.; Khlebnikov, A. I.; Quinn, M. T. J. Med. Chem. 2007, 50, 4928-4938. doi:10.1021/jm070600+

39. Baraldi, P. G.; Vicentini, C. B.; Simoni, D.; Menziani, E. Farmaco, Ed. Sci. 1983, 38, 508-513.

40. Walczak, K.; Gondela, A.; Suwiński, J. Eur. J. Med. Chem. 2004, 39, 849-853. doi:10.1016/j.ejmech.2004.06.014

41.Lu, I.-L.; Mahindroo, N.; Liang, P.-H.; Peng, Y.-H.; Kuo, C.-J.; Tsai, K.-C.; Hsieh, H.-P.; Chao, Y.-S.; Wu, S.-Y. J. Med. Chem. 2006, 49, 5154-5161. doi:10.1021/jm060207o

42. Penning, T. D.; Talley, J. J.; Bertenshaw, S. R.; Carter, J. S.; Collins, P. W.; Docter, S.; Graneto, M. J.; Lee, L. F.; Malecha, J. W.; Miyashiro, J. M.; Rogers, R. S.; Rogier, D. J.; Yu, S. S.;

Anderson, G. D.; Burton, E. G.; Cogburn, J. N.; Gregory, S. A.; Koboldt, C. M.; Perkins, W. E.; Seibert, K.; Veenhuizen, A. W.; Zhang, Y. Y.; Isakson, P. C. J. Med. Chem. 1997, 40, 1347-1365. doi:10.1021/jm960803q

43. Zapol'skii, V. A.; Namyslo, J. C.; Gjikaj, M.; Kaufmann, D. E. Synlett 2007, 1507-1512. doi:10.1055/s-2007-982554

\section{License and Terms}

This is an Open Access article under the terms of the Creative Commons Attribution License

(http://creativecommons.org/licenses/by/2.0), which permits unrestricted use, distribution, and reproduction in any medium, provided the original work is properly cited.

The license is subject to the Beilstein Journal of Organic Chemistry terms and conditions:

(http://www.beilstein-journals.org/bjoc)

The definitive version of this article is the electronic one which can be found at:

doi:10.3762/bjoc.8.69 